\title{
Françoise Noël \\ Family and Community Life in Northeastern Ontario: The Interwar Years
}

Montreal and Kingston: McGill-Queen's University Press, 2009. 349 pp.

\section{Cynthia Comacchio}

Wilfrid Laurier University

The title of Françoise Noël's study succinctly describes what readers will find within its covers: this is a careful, meticulously-researched and engaging account of family and community life during the twenty-odd eventful years bounded by two world wars. The geographic expanse of Northeastern Ontario encompasses the area from Mattawa, near the Quebec border, to Lake Nipissing. What Noël manages to uncover for this region and this period, by painstakingly layering her multiple sources of evidence, is a fascinating picture of the quotidian lives of ordinary people in what frequently amounted to extraordinary conditions, such as poverty and isolation, against the backdrop of such extraordinary world-historic events as the Great Depression.

Focusing on family and community permits the author to get at what her subjects shared, their lives delimited, though not entirely defined, by the identifying categories of class, gender, race, language, religion and age. Despite contemporary understandings of such historic markers of status and role, individuals could, and not infrequently were obliged to, bend these confines if not step outside them. Thus married women, notwithstanding social and religious pressures against wage-earning, contributed significantly to the precarious family economies of many settlers. And notwithstanding the growing public emphasis on schooling rather than work for children, here, too, familial and community views and practices were necessarily contingent and flexible, in keeping with the needs, short and long-term, of particular families as well as their individual members. Above all, Noël effectively demonstrates how flexibility and adaptability were the hallmarks of family life in these workingclass resource communities. We see quite clearly the lived meaning of what was once the key concept in the social historian's lexicon, the now almost quaint-sounding notion of "agency." Noël capably shows how these ordinary people negotiated and 
accommodated the needs, and even a few of the desires, of individual members or the family group, in networks of mutual assistance that often extended beyond the household and the nuclear unit, and even beyond the ties of blood and law, into the wider community.

In a number of ways, this book is an example of classic social-historical analysis. Noël's overall approach reflects her own training in microhistory and historical demography, and this permits a solid scaffolding of vital information derived from the standard documentary sources such as government, local and census records. On this foundation, she deftly works to fill out what the "official" data cannot tell by means of a close reading of local and regional media, allowing for a sense of the closer and more immediate community context. Most remarkable is the final layer, in which she has teased out, through examination of the letters, diaries, and memories of the historical actors who constituted the families and communities of the larger story, the details of private life for which historians so yearn.

Forty-three interviews form the heart of this "inside" portrayal of family and community life in Northeastern Ontario during the 1920s and 1930s. Given the expanse of time that has elapsed since her subjects' childhoods, we can be especially grateful that Noël was able to garner as much information as she has. She took care to seek out a "representative" sampling from the varied anglophone, francophone, and immigrant (in large part Italian) households in her communities, thereby presenting glimpses of cultural differences as these operated in family and community, but also of the ways in which other elements, having more to do with class, gender, age and family position, often complicated what might appear to be simply "cultural." Also evident are the ways in which the family and community ties of the individuals shine through their memories to suggest commonalities of experience transcending other, narrower, frequently restraining influences such as the race and gender constructions of the time. The three family stories that animate this analysis are endearingly "real." The two women are, respectively, members of working-class Italian immigrant and French-Canadian families, while the male participant has an anglo-Canadian/Irish background. Most striking about their vivid recollections is the intertwining of family and community through neighbourhood, school, playground, church, social and "ethnic" organizations, rituals and celebrations.

Noël's consideration of the Depression experience indicates its uneven impact even within the region. In Northeastern Ontario's rural communities, the economic effects were relatively muted, while urban families were subject to a range of experiences, depending, as elsewhere, on the employment status of the male breadwinner and the ability of other family members to replace his reduced or lost earnings. The fact that most of the childhood memories recalled from that dark time are not themselves dark is significant, suggesting as it does that family and community ultimately played important roles in assuaging the anxiety and insecurity that would otherwise have imprinted the growing up process and consequently adult recollections.

There is no question that family and community life for the Northeastern Ontario residents of the interwar years was fashioned out of their resourcefulness, "making do," endurance, courage, and just plain hard work in and outside of the home. Noël, 
following Neil Sutherland's conceptualization of the "scripts" that underlie and configure childhood memories, has done a first-rate job of revealing ordinary lives in their recounting. The only disappointment is that this script-approach remains implicit in the analysis; I wanted to see a more probing interpretation of why things were remembered as they were along with how they were remembered, for all that the latter is so valuable in any attempted understanding of past lives. There is a tendency to use this material in illustrative fashion, to sustain the narrative threads, so to speak, rather than analytically, as an integral part of the history of these families and these communities and their many interrelations. That said, this book offers much to historians of childhood and family, historians of Northern Ontario, and quite simply social historians of all stripes and leanings who will appreciate the rigorous and impressive scholarship that Françoise Noël presents here for our personal enrichment, as much as that of the field. 